\title{
The Impact of Pupuk Kaltim's Creating Shared Value (CSV) program for Fishermen on Tanjung Limau Bontang
}

\author{
Sri Djuwani Ekowati ${ }^{1}$, Sudharto P Hadi $^{2}$ \\ ${ }^{1}$ Doctoral Program in Environmental Sciences, Post-Graduate School, Diponegoro University, Semarang-Indonesia \\ ${ }^{2}$ Professor at Graduate Program of Environmental Science Diponegoro University, Semarang -Indonesia
}

\begin{abstract}
Bontang area is ocean. There are two large factories in Bontang, they are PT. Pupuk Kaltim (PKT) in Bontang Utara District and PT. Badak NGL in South Bontang District. Pupuk Kaltim's CSR implementation, since the operation of the factory from 1979 to 2015, is still charitable. Thus, the implementation of CSR does not have much impact on both the community and the company. Local people often protest the company by using environmental issues, namely the large number of dead fish caused by environmental pollution from PKT factory's liquid waste. They sometimes close the ship's entry and exit lanes from the PKT's factory port. In 2016, PKT implemented the Creating Shared Value (CSV) program at Tanjung Limau. This program is a program for sharing the results of PKT CSR with local fishermen through lobster and grouper cultivation on Floating Net Cage (FNC). The aim is to identify the economic, social and natural impacts on Tanjung Limau fishermen groups who are members of the PKT CSV program. Data was collected from BMTFEC diaries from 2016 to 2018 through Focus Group Discussions (FGD), interviews, and questionnaires. The results show that the income of members of the fishing group ranges from IDR 2,000,000 per month, is more environmentally friendly, members of the fishing group increase, and they get access to new markets.
\end{abstract}

Keywords: CSV; Revenue Sharing; Floating Net Cage (FNC).

\section{Introduction}

According to the experts, there are three definitions of CSR; First, business commitment to contribute in building a sustainable economy. The company works and interacts positively with employees, families, and communities around the company. It aims to improve the quality of life together. Second, business commitments are carried out ethically and operate legally. In addition, companies also contribute to improving the economy followed by improving the quality of life of employees to the community. Third, as a social action, including caring for the environment that is more than the limit needed or needed in the law. From the several meanings of the existing CSR, CSR itself is strongly associated with sustainable development where the company prior to the activity must be based on a decision that is not only thinking or oriented to the economic aspects but must also consider social and environmental aspects [1].
In Romania, companies that carry out social responsibility are valued only for the sake of the company's image, business reputation or interests and stakeholder needs not for sustainable development [2]. In Malaysia, many public companies are late responding to CSR such as environmental preservation and social welfare of the communities where the company operates [3]. The results of the 2011 Asia CSR report contain global issues about corruption and the increasing number of poverty so that it puts Asia in the spotlight for sustainable development [4]. The concept of CSR creates social change and enhances the dynamics between companies and local communities and stakeholders, [5]

In Indonesia, companies that implement environmental performance are more than those who meet the requirements (exceed compliance) and implement CSR by empowering the community around the company to be given the Right Ranking (Ranking of Corporate Performance Programs in Environmental Management) by the government.

\footnotetext{
*Corresponding author: sekowati@pupukkaltim.com
} 
And that together with Gold Rating, which is the highest award from the Indonesian Ministry of Environment and Forestry in managing the environment and CSR well. Disclosure of CSR and Environmental Performance simultaneously has a significant effect on Return on Equity (ROE) and ROA Return on Asset [6].

There are four types of programs in CSR, namely; First, Charity. This is a CSR program in the form of free assistance from companies such as basic food assistance during Eid al-Fitr, mass circumcisions, free medical care, etc. This CSR program is like "giving them fish" rather than "teaching them to fish". Second, Infrastructure. It is a CSR program that focuses on improving physical buildings used for public facilities such as the construction of highways, school buildings, bridges, and others. Third, Capacity Development. It is a CSR program that increases individual/community capacity, but there is no continuation, for example, sewing training, comparative studies, and others. Fourth, Empowerment of Community Development. It facilitates communities to support sustainable livelihoods so that they can be independent. [7].

The companies that use natural resources must implement CSR [8]. In this case, PKT uses methane (CH4) natural gas as raw material for making ammonia (NH3) and urea fertilizer, so companies are required to carry out social responsibility. PKT is a subsidiary of the Holding Company namely Pupuk Indonesia (PIHC) along with four other fertilizer factories.

Before 2015, most of the CSR programs carried out by PKT were in the form of charity and not empowerment, so that the company's CSR programs do not have much impact on the communities. Quoting the principle of Creating Shared Value (CSV) from [9] states that CSV must be in line with the company's business and there is value for, while the main business of the PKT for urea and NPK is closely related to agriculture. Because Bontang area is $70 \%$ sea and $30 \%$ land, there is no development on agricultural land in Bontang. The fishermen catch fish using explosives and also fish poison of potas. They are also entangled with intermediaries. Therefore, PKT gradually shifted its CSR programs which began in the form of charity for empowerment on the basis of Creating Shared Value (CSV) model for local communities. The livelihoods of the people around the company are as fishermen. To realize the CSV program, the first step conducted by PKT was to gather fishermen from various villages in Bontang such as Gusung Village, Lhoktuan Village, Gunung Elai Village, Bontang Kuala Village, and Tanjung Laut Indah Village, which consisted of 10 fishermen to discuss apprenticeships in Tanjung Lesung Banten.
Previously PKT had conducted a survey at the location. The ten fishermen were accompanied by staffs from Bontang Fisheries Office/Affairs and one of the CSV teams conducted an apprenticeship in Tanjung Lesung Banten for 4 days to studying grouper cultivation and lobster cultivation in the Floating Net Cages (FNC), making fish feed in the form of pellets, and forming a cooperatives for fishermen.

In the Second Stage, PKT invited fishermen to intensive discussions after returning from an internship in Banten. The information obtained was that the fishermen wanted to form a legal cooperative from groupers and a lobster fish farming cooperative as had been carried out by fishermen groups in Banten. The Third Stage, PKT increased fishermen's capacity for knowledge about cooperatives, how to raise groupers and lobsters at the FNC, and increased the competence of fishermen by holding One-Day Knowledge Sharing Activities from PKT Employee Cooperative and Bontang Cooperative Office, sharing knowledge from the Faculty of Fisheries (Riau University), as well as training and certification of good fish farming methods.

These four stages of PKT are in cooperation with Bontang Cooperative Office and Bontang City Fisheries Service to assist groups of fishermen at Tanjung Limau in forming fisheries cooperatives with legal status for 2 months. Thus, the fisheries cooperative was formed under the name of Bontang Maritime Tourism and Fisheries Economic Cooperative, abbreviated as BMTFEC. This cooperative has received a Cooperative Registration Number. FNC and seeds of Grouper are provided by PKT. Meanwhile, the fishermen do the maintenance and fish feeding. Harvest at the FNC is an additional income and do not replace livelihoods as fishermen. The average additional income of these fishermen reaches IDR 2,000,000 per month from profit sharing with the company. The result of this empowerment is that the fishermen are wiser, environmentally friendly, and the social cohesion between the senior and the junior fishermen is more intense. The purpose of this study is to identify the economic, social and natural impacts of the group of fishermen at Tanjung Limau in participating in the PKT-CSV program.

\section{Methods}

\subsection{Fisherman Internship}

At the end of 2016, PKT carried out one of the Coastal CSR programs by sending 10 fishermen including local heroes from various villages in Bontang Utara to Pandeglang Tanjung Lesung, Alam 
Bahari Banten Cooperative for 4 days. They have 400 FNC plots, the price per plot for $3 \mathrm{~m} \times 3 \mathrm{~m} \times 3.5 \mathrm{~m}$ (31.5 meters square) is around IDR 300,000,000,-. The aim of this program is to intern and study grouper and lobster cultivation, work together, and make fish pellets in the modern FNC from government assistance.

After returning from Banten, Pak Maeng as a local hero initiated the establishment of the FNC. He has the expertise to assemble the FNC and teach his expertise to other fishermen to make 12 FNCs with a size of $4 \mathrm{~m} \times 4 \mathrm{~m} \times 3.5 \mathrm{~m}$ (56 meters square) and fishing gear.

PKT provides materials for making FNCs and fishing gear using local materials such as Kayu Ulin or local ironwood and uses used chemical drums from PKT that have been cleaned and provide nets as well.

\subsection{Seeds Providing}

Because grouper seeds in Bontang are not yet available, they are purchased from the Central Office of the Ministry of Maritime Affairs and Fishermen in Gondol-Bali based on the directions from Bontang Fisheries and Agriculture Food Security Office. PKT bought 4000 beautiful grouper seeds from Gondol Bali for IDR 13,000 each and the price does not include the shipping yet. Lobster seeds are bought from around Bontang at IDR 50,000 per 100 grams.

Grouper fish seeds come from Gondol Bali and Situbondo in East Java with a size of $10 \mathrm{~cm}$. The grouper seeds are kept in FNC for about 10 months to reach a premium size weighing around 0.5 to $0.9 \mathrm{~kg}$ each. During the harvest period, buyers from Makassar come by boat to buy groupers at a price of IDR 100,000 per kgs. Then the fish will be exported to Taiwan. For the lobster seeds, they are obtained from around Bontang sea because there is no lobster nursery yet.

\subsection{Training on High Quality Fish Cultivation (THQFC)}

CSV-PKT conducted a Training on High Quality Fish Cultivation (THQFC) for 30 fishermen for 2 weeks to increase their capacity; the trainer came from Bitung Training Center. The lessons learned were how to treat fish well in FNC, water analysis, and net cleaning. After the training, a competency test was conducted. Those who graduated received a THQFC certificate. The usefulness of THQFC certificate is not only as the evidence of the competency of Tanjung Limau fishermen but also useful for the sale of fish products to buyers, especially those who access the market, and especially foreign markets who always request THQFC certificates.

\subsection{Establishment of Fishermen Cooperative}

Based on the previous experience of PKT in implementing CSR programs in collaboration with individuals, PKT is highly dependent on one's performance and often fails. From this experience, PKT encourages fishermen in Tanjung Limau to establish Fishermen Cooperative. Together with Bontang City Cooperative Office, fisheries extension workers, and PKT Employee Cooperative, the fishermen established an official fishing cooperative. Then in November 2017, Bontang Maritime Tourism and Fisheries Economic Cooperative (BMTFEC) was established with 30 members, and Mr. Mukhtar was chosen as the chairman. In April 2018, the first Annual Member Meeting was successfully held even though there was no remaining profit distributed to the members.

\subsection{Mentoring Program}

During the implementation of CSV program, BMTFEC was accompanied by fisheries instructors from the Ministry of Maritime Affairs and Fisheries who were placed in Bontang Fisheries and Food Safety Service, Community Development Officers (CDO), and CSV-PKT Team. There was an agreement that FNC is the property of PKT, while BMTFEC is fully assigned to manage the FNC. Sales net profit is divided equally by $50 \%$ each from fishing companies. At present, BMTFEC has 70 members, is managing 96 FNCs in Tanjung Limau and 12 FNCs in Gusung as well as the supporting facilities.

\subsection{Related institutions}

Institutions involved in supporting the existence of the BMTFEC are the Ministry of Maritime Affairs and Fisheries of the Republic of Indonesia, Bontang Fisheries and Security Office, East Kalimantan Provincial Environment Agency, Bontang Environment Agency, the Natural Resource Conservation Center, the Women's Empowerment and Protection Agency for Bontang, the North Bontang District Head and the local village head. 


\subsection{Making a Strategic Plan}

The target achieved is the development of the Floating Net Cage (FNC), which is outlined in a Strategic Plan made for 5 years as outlined in the Road Map. Furthermore, the Strategic Plan makes annual plans and conducts monitoring and evaluation so that deviations from the initial target can increase, and the target can be achieved.

\subsection{Profit Sharing Agreement}

PKT with BMTFEC has made an agreement for profit sharing agreed by both parties in grouper cultivation, especially in supplying grouper seeds. This agreement is stated in the MoU and signed by both parties. PKT is represented by the Chair of the CSV Team and BMTFEC is represented by the Head of it. Formulation of profit sharing:

Profit sharing $=(($ Total sales $-($ purchase of seeds + purchase of feed + security) $) / 2) \times 100 \%$

If it is the fishermen who provide grouper seeds and feed them, not all proceeds from the sale of the fishermen are shared with the company. The difference between this research and the previous research is that $\mathrm{CSR}$ is directed at community empowerment and profit sharing if the company provides grouper seeds.

Fish harvesting has been done 3 times. At the First harvest, there are 3 tons of seeds from Gondol Bali and natural seeds. At the second harvest, there are 2.5 tons of seeds from Gondol Bali and natural seeds. Meanwhile, at the third harvest, there are 2 tons of natural seeds with different duration of time between harvest times. When the fishermen catch small fish, they are not immediately sold to the market but stored in the FNC or enlarged until they reach a minimum weight of $0.5 \mathrm{kgs}$. Hence, it is expected that the dependence of the fishermen on the supply of seeds from Pupuk Kaltim will decrease.

If Pupuk Kaltim provides the seeds, the net profit is divided equally. Pupuk Kaltim gets 50\% and BMTFEC also gets 50\%. Pupuk Kaltim's sharing profit is used for FNC replication in Gusung Guntung Village.

\subsection{Data Collection}

The Data collection was obtained from 27 people of 30 members of the cooperative who received the form. They fill in the form about their average monthly income in 2017 and 2018. This form is intended for BMTFEC members who have received FNC and are working on cultivation in FNC with natural seeds (self-search results) or seeds provided by PKT, then the data is calculated by using MS. Office Excel program so that the average income of the fishermen per month is obtained.

\section{Results}

In monitoring and evaluation (monev) for the implementation of CSV at PT. Pupuk Kaltim refers to Compass Analysis Sustainability in accordance with wind direction, the East $(\mathrm{E}=$ Economic $)$ in terms of economic growth, North $(\mathrm{N}=$ Nature $)$ in terms of the environment, South $=(S=$ Social $)$ in terms of social side, West ( $\mathrm{W}=$ Wellbeing) in terms of comfort. For the empowerment of Tanjung Limau coastal communities for compass sustainability, it is described as follows:

\subsection{Economic Side}

Economic growth from additional income of BMTFEC members per month is around IDR 1,985,540,- (without intermediaries). They have new market access. Buyers come by their own boat from Kendari to buy alive groupers at FNC Tanjung Limau. Then the fish are exported outside Indonesia. If the groupers harvest is above 1 ton, BMTFEC can determine the groupers selling price that refers to international market prices and they may have access to local markets around Bontang such as restaurants/grilled fish stalls. CSV-PKT also establised a food stall at FNC Tanjung Limau. The stall was named "Kerlob-Kerlob" and it provides grilled groupers and grilled lobsters.

\subsection{Social Side}

From the social side, there is a new institution namely Bontang Maritime Tourism and Fisheries Economic Cooperative or BMTFEC with the Registration Number of G472020201002. The increasing of its membership is from 10 members in 2016 into 70 members at the end of 2018. BMTFEC has a secretarial office provided by Mr. Mukhtar as the chairman. The existence of this secretariat is very useful for members gathering or when there are meetings in discussing the program between CSVPKT and BMTFEC team.

The social cohesion among members becomes increasingly tight, and both BMTFEC and PKT get to know each other much better. If there is a problem related to dead fish in FNC due to natural factors, this will be discussed better than before. Then the local fishermen are no longer suspect PKT anymore for the environmental issues or close the ship lane of PKT. 
Now BMTFEC can say that PKT has managed liquid waste well so that the presence of FNC CSV-PKT managed by BMTFEC can be used as an indicator of the success of PT. Pupuk Kaltim in managing its liquid waste.

The comparison of this research in terms of social when compared with other studies is the formation of a cooperative as an official institution that is legally recognized and has a registered number. Thus, this makes its existence get better. From the environmental side, the savings obtained after the use of Solar Cells are IDR 50,000, - per night from the cost of purchasing 5 liters of gasoline for FNC lighting per night.

\subsection{The Environment Side}

The behavior of BMTFEC members towards the environment has improved. They no longer use explosives when catching fish, do not throw trash in the sea, harvest rainwater for water supply in the toilet, and build toilet that is equipped with waste treatment. The reason why the behavior of the fishermen towards the environment is improving is because the company (PKT) has conducted socialization to maintain the cleanliness of the marine environment so that it is not polluted. They are urged not to use bombs when catching fish and destroying the corals where fish gather. The socialization from the Natural Resources Conservation Agency also concerns about the various types of protected marine animals, so that their knowledge is improving. From the well-being side, their competence also increase 80 percent more than before. For lighting at night, the FNC uses solar cells that are renewable energy, not fossil energy. The use of solar cells reduces pollution and saves the use of fossil energy. For the solar cell installation, CSV and FNC are collaborating with students and lecturers from the Technical College in Bontang. The good behavior of these fishermen can be seen when they go out to the sea and unintentionally catch hawksbill sea turtles and Napoleon fish that are protected fish, they bring their catch to FNC for sanitation. If the condition of the Napoleon hawksbill and turtles has recovered and is healthy again, they will be released back to the sea. Some time ago, they released 7 hawksbill turtles and 5 Napoleon fish. 4 Napoleon fish were less than $1 \mathrm{~kg}$ each and 1 other fish was more than $3 \mathrm{~kg}$ each. The release was carried out jointly with Bontang City and Provincial Fisheries Service, and Tarakan, Pupuk Kaltim and BMTFEC Fisheries Service on April 25,
2019. In coral reef areas, Pupuk Kaltim has carried out conservation since 2009 until now along with other Pupuk Kaltim assisted communities; namely the reef group in Tobokbatang because there are around 4000 reefs in this area.

Before that, if BMTFEC members unintentionally caught hawksbill sea turtles, they would kill them and have their flesh sold in the market. If Napoleon fish got caught unintentionally, they were directly sold to buyers who were interested in buying them illegally. But after BMTFEC was established, fishermen were already given information about some protected species of fish and marine animals so that they understood and more cared about it.

Table 1. The behavior of BMTFEC Members before BMTFEC was established

\begin{tabular}{|c|l|}
\hline No. & $\begin{array}{l}\text { Members Before BMTFEC was } \\
\text { establised }\end{array}$ \\
\hline 1. & Used explosives material when fishing \\
\hline 2. & No garbage disposing into the sea \\
\hline 3. & $\begin{array}{l}\text { Not harvesting rainwater for toilet water } \\
\text { supply }\end{array}$ \\
\hline 4. & $\begin{array}{l}\text { Toilets were not equipped with waste } \\
\text { processors }\end{array}$ \\
\hline 5. & Fossil energy \\
\hline 6. & $\begin{array}{l}\text { Caught hawksbill turtles and then killed } \\
\text { and their meat sold in the market }\end{array}$ \\
\hline 7. & $\begin{array}{l}\text { Caught Napoleon fish sold directly } \\
\text { interested buyers illegally }\end{array}$ \\
\hline
\end{tabular}

Table 2. The behavior of BMTFEC Members after BMTFEC was established

\begin{tabular}{|cl|}
\hline No. & $\begin{array}{l}\text { Members Behavior After BMTFEC was } \\
\text { established }\end{array}$ \\
\hline 1. & No explosives material used when fishing \\
\hline 2. & No garbage disposing into the sea \\
\hline 3. & Harvesting rainwater for toilet water supply \\
\hline 4. & Toilets were equipped with waste processors \\
\hline 5. & Renewable energy \\
\hline 6. & $\begin{array}{l}\text { Well educated in treating the hawksbill turtles } \\
\text { and Napoleon Fish that caught unintentionally }\end{array}$ \\
\hline
\end{tabular}




\subsection{Well-being Side}

The well-being of BMTFEC members has increased with additional income from grouper sales at harvest and culinary business of "Kerlob-Kerlob" stall which provides grilled lobster. Members' competency also increases with certification of good fish farming methods. Members' competence in nautical fishing boat III and basic safety also has increased 80 percent more than before. They also understand better about sea traffic signs, and have market access for fish sales both domestically and internationally. Their confidence also increased by submitting proposal for ships and ice machines to Indonesian Ministry of Maritime Affairs and Fisheries. The proposal was realized and they got 3 ships with a capacity of 3 Gross Tons and 1 ice maker for fish preservation [10].

\section{Conclusion}

The CSV-FNC program for fishermen in Tanjung Limau based on the Compass Sustainability Evaluation is summarized as follows:

1. Additional income of almost 2 million per month for the cooperative members.

2. The meals provided are delicious and the staffs are friendly and very clean.

3. Establishing BMTFEC Cooperative, which has legal entity and has a legal cooperative registration number, and the social cohesion of inter-generation is increased as well.

4. Access to new markets in fish sales domestically and internationally.

5. Fishermen are more environmentally friendly.

6. Fishermen are more easily invited by the company and no longer obstruct the shipping lanes of fertilizer buyers of the company (PKT).

7. As a bio indicator that PT. Pupuk Kaltim has managed its liquid waste well and properly in accordance with the legislation regulations.

8. Inventory items provided by the company (PKT) are better maintained so that nothing is lost anymore, and BMTFEC members are more concerned towards FNC.

\section{References}

1. R. Brian, Pengertian CSR Menurut Para Ahli, Manfaat, Fungsi, Serta Contohnya, Retrieved from https://www.maxmanroe.com/pengertiancsr.html in June 22 (2019)

2. R.A. Popa, The Corporate Social Responsibility Practices in The Context of Sustainable
Development. The Case of Romania, Procedia Economics and Finance 23, 1279-1285 (2015)

3. S.A. Mustafa, A.R. Othman, S. Perumal, Corporate Social Responsibility and Company Performance in the Malaysian Context, Procedia - Social and Behavioral Sciences, ICIBSoS 65, 897-905 (2013)

4. S.R. Waworuntu, M.D. Wantah, T. Rusmanto, CSR and Financial Performance Analysis: Evidence from Top ASEAN Listed Companies, Procedia - Social and Behavioral Sciences 164, 493-500 (2015)

5. A.E. Fordham, G.M. Robinson, Mapping meanings of corporate social responsibility - an Australian case study, International Journal of Corporate Social Responsibility 3(1), 14 (2018)

6. D. Angelia, R. Suryaningsih, The Effect of Environmental Performance And Corporate Social Responsibility Disclosure Towards Financial Performance (Case Study to Manufacture, Infrastructure, And Service Companies That Listed At Indonesia Stock Exchange), Procedia - Social and Behavioral Sciences 211, 348-355 (2015)

7. S.P. Hadi, Tanggung Jawab Sosial dan Lingkungan Perusahaan (2019)

8. Republik Indonesia, Undang-Undang Republik Indonesia Nomor 40 Tahun 2007 Tentang Perseroan Terbatas (2007)

9. M.E. Porter, M.R. Kramer, Creating Shared Value, Harvard Business Review (2011)

10. T.P. Pkt, CSR Pupuk Kaltim Mewujudkan Masyarakat Mandiri dan Berkelanjutan, 1-38 (2017) 